\title{
Cell Layout Application in Product Recovery: A Lean Proposal to Increase Efficiency in Remanufacturing
}

\author{
Marina Bouzon, Carlos M. Taboada Rodriguez, Abelardo A. de Queiroz \\ Federal University of Santa Catarina, Florianópolis, Brazil
}

\begin{abstract}
The growing demand of organizations for alternative technologies to reduce environmental damage and meet new legislative issues brought greater focus to the activities of product recovery. One way to recover and revalue a product is by remanufacturing, which is defined as the process of recovering a product to its original specifications, promoting the reuse of materials and improving its quality and functionality. However, the context of the remanufacturing industry faces difficulties and is considered unstable and inefficient if compared to manufacturing. In this sense, this paper aims to propose a cell layout based on lean concepts and adapted to the context of remanufacturing, aiming to minimize waste, reduce variability and thereby increase efficiency. The cell layout proposal was based on a literature review and researchers' practical experience in the area. This layout can provide the flexibility to handle the variations inherent in the context of remanufacturing, boosting product recovery and related environmental issues.
\end{abstract}

Keywords: remanufacturing, cell layout, lean remanufacturing, product recovery

\section{Introduction}

The current extraction rate of terrestrial crust material is not sustainable, not only due to limited resources, but also to the production of trash and waste related to the extraction. Therefore, material cycles must be closed in order to achieve a state of sustainable development-one that meets the needs of today without compromising the needs of future generations (Sundin, 2006). Additionally, legislative issues emerged regarding the end of life of products, such as End-of-life Vehicles Directive (ELV) and Waste Electrical and Electronic Equipment Directive (WEEE) (Kumar \& Putnam, 2008).

In face of this environmental scenario as well as social and governmental pressures, academia and the business community initiated a search for alternative technologies that reduce environmental damage and that are more suitable for the new legislative issues. One approach is focused on the process of product recovery, in order to minimize waste generation by the revalorization of products and materials and meet legislative and social demands.

One of the most common means of product recovery is remanufacturing, defined as the process of recovering a worn-out/broken/used product to its original specifications through an industrial process,

Marina Bouzon, Master, Production Engineering Department, Federal University of Santa Catarina.

Carlos M. Taboada Rodriguez, Ph.D., Production Engineering Department, Federal University of Santa Catarina.

Abelardo A. de Queiroz, Ph.D., Mechanical Engineering Department, Federal University of Santa Catarina.

Correspondence concerning this article should be addressed to Marina Bouzon, PPGEP Caixa Postal 476-CEP 88040-900

Universidade Federal de Santa Catarina-UFSC, Brazil. E-mail: marinabouzon@gmail.com. 
promoting the reuse of materials and improving its quality and functionality (Bouzon, Cardoso, Queiroz, \& Gontijo, 2010). It has many benefits, the most important being: the economy of material, energy, capital, manpower, and emissions that were employed in manufacturing, and the final cost, which is usually less than that of manufacturing, allowing sales by prices $25 \%$ to $50 \%$ smaller (Amezquita \& Bras, 1996).

However, even considering its benefits, this industry still has many challenges to overcome. Remanufacturing systems remained untouched by the advances in technology, productivity, and quality in the last 30 years (Kucner, 2008). Remanufacturing has factors that limit its development if compared to traditional manufacturing. The challenge of remanufacturing is the production of quality products from returned discarded cores of unknown quality (Parkinson \& Thompson, 2004). This creates variability in processes, hindering process standardization, generating waste and efficiency problems.

Considering the context discoursed, this article presents a proposal for a cellular layout based on lean philosophy and aimed to the remanufacturing environment in order to minimize waste, seek continuous flow, and increase the efficiency of their processes. The paper is divided into six chapters. Section 2 deals with lean manufacturing concepts. Section 3 contains an explanation of cell layout design and application. Section 4 focuses on remanufacturing. Section 5 presents the proposal of cellular layout for remanufacturing. And finally, section 6 discusses final remarks and future research in the area.

\section{Lean Manufacturing}

Lean manufacturing was originated in Japan in the 1950s, at Toyota Motor Company (Womack, Jones, \& Roos, 2004). Its main goal is to produce more with fewer resources, with focus on the client (Liker, 2004). For this, it is based on five lean principles.

\section{Lean Principles}

Lean thinking is a way to specify the value, better align the sequence of actions that create this value, perform these activities without interruption whenever requested and in a progressively effective way. That is, lean thinking may be summarized in five principles:

(1) Value: must be defined from the perspective of the end customer, expressed in terms of a specific product that meets the same needs;

(2) Value stream: the set of all actions necessary to conduct a specific product by the product development flow, order flow, and production flow (Womack \& Jones, 2004);

(3) Creating flow: create the value stream based on the obtained value chain, so that it occurs without interruption, in order to reduce non-value added activities (Womack \& Jones, 2004);

(4) Pull: the client pulls the production of a good or service, avoiding the worst waste-overproduction (Ohno, 1997);

(5) Perfection: relentless pursuit of the "ideal", with the complete elimination of waste (continuous improvement).

The elimination of waste is present in each of these principles and, consequently, lean thinking becomes a powerful antidote to combat waste (Womack \& Jones, 2004).

\section{Waste}

It is understood by waste any activity that adds no value to the product regarding customer requirements (Womack \& Jones, 2004). Waste or "mudas" are usually subdivided into seven types: overproduction 
(producing more than necessary or ahead of time), wait (of materials or people), unnecessary transport (materials), improper processing, inventory, unnecessary movement (people), and production of defective products (Ohno, 1997).

One way to minimize waste in a production system is the use of a physical arrangement in cell configuration: the cellular layout. This arrangement minimizes the physical distances covered by operators and products, enables the interchangeability of operators in the workplace, facilitates the supply of materials, and enables the reduction of work in process (WIP) in order to expose the waste.

\section{Cellular Layout}

The layout of a productive operation covers the physical location of transformation resources (Slack, Chambers, \& Johnston, 2008). For lean principles to flow, the production lines should be arranged so as to meet the requirements of lean thinking. Planning the layout of the productive sector involves decisions on how resources will be arranged and how work stations should be distributed in order to facilitate the movement of people and materials.

A traditional production line is a unitary system in which products move through a sequence of stations, each equipped with the materials, machinery, tools, operators, and instructions needed to perform the work, where each unit is processed and passed on to the next station (Baudin, 2002). A lean production line, or cell, is an arrangement of people, machines, materials, and methods in which the process steps are close and occur in sequential order, by which the parts are processed in a continuous flow or in small batches (Rother \& Harris, 2002). One way to arrange a lean production line is in the shape of "U”, as Figure 1 shows.

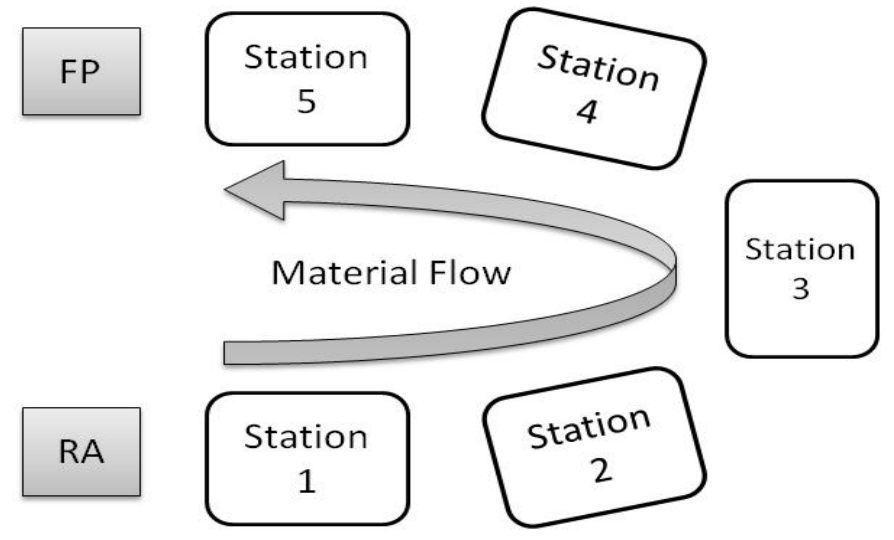

Figure 1. Example of cell layout in the form of "U”.

Figure 1 illustrates the layout of a manufacturing cell. The raw material (RM) begins its transformation in work station 1 and goes until station 5, where it is stored in predefined batches of finished product (FP). From the cell, the FP can go to a warehouse of finished goods or directly to the client.

From the perspective of resources, the cell is seen as a small group of human and technical resources dedicated to a family of products. Therefore, it is not recommended to allocate more than 12 operators in a cell. More than that hinders the cohesion of the working group (Hyer \& Wemmerlöv, 2002), thus diminishing the benefits of a team work.

From the perspective of space, a cell must be arranged very close to the resources and with clear physical boundaries. The closer the resources, the more efficient the cell (Hyer \& Wemmerlöv, 2002), and the most 
favorable width of the inner side of a cell in the shape of " $U$ " is about 1.5 meters (Rother \& Harris, 2002). This minimizes the distance covered and the possibility of accumulation of material between operations, enabling interchangeability of multifunctional operators.

\section{Choosing Products for a Cell}

Some guidelines should be considered to determine the products to be manufactured in a cell. A cell can be dedicated to a product if there is high and stable demand, or for various products of a family whose total demand is more stable. The variation in work content for the products of the cell should not vary more than $30 \%$ in terms of productive time, for if the content varies widely, there will be difficulty in keeping the flow and productivity. In this sense, the process steps and equipment used must be similar to the products of the cell in order to facilitate the standardization and quality control and increase productivity. At last, the cell production rhythm or takt time (time available for production divided by demand) should be between 10 and 120 seconds (Rother \& Harris, 2002).

\section{Advantages and Disadvantages of the Cellular Layout}

There are many reasons for producing in cell: reduction of lead time and inventory (Hyer \& Wemmerlöv, 2002). Table 1 contains advantages and disadvantages of this layout.

Table 1

Advantages and Disadvantages of a Cellular Layout

\begin{tabular}{|c|c|}
\hline Advantages & Disadvantages \\
\hline $\begin{array}{l}\text { Increased flexibility in batch size by product: enables the production in } \\
\text { smaller batches, and therefore, improves the flow. } \\
\text { Decreased transport of material: the distances traveled by the material } \\
\text { in the cell are generally smaller. } \\
\text { Decrease of stocks: with a decrease of lots and reduction of waiting } \\
\text { times for items in processing, there is stock reduction. } \\
\text { Greater job satisfaction: better rapport among employees of the same } \\
\text { cell, due to the physical proximity. } \\
\text { Adaptation to demand: the layout enables better adaptation to } \\
\text { variations in demand. }\end{array}$ & $\begin{array}{l}\text { Route flexibility: once the equipment is removed } \\
\text { from the work centers and placed in the cell, the } \\
\text { flexibility of route is decreased, leaving the cell more } \\
\text { sensitive to variations in workload. } \\
\text { Product flexibility: dedicating equipment and } \\
\text { people to a cell reduces the ability to manufacture new } \\
\text { products. This disadvantage can be solved with } \\
\text { equipment and operators with greater flexibility. }\end{array}$ \\
\hline
\end{tabular}

Note. Source: Adapted from Peinado and Graeml (2007) and Hyer and Wemmerlöv (2002).

Besides the advantages listed in Table 1, the cellular layout avoids directly three of the seven types of waste. They are: the operators waiting for material, equipment, or other operators; unnecessary transport of materials or products over long distances; unnecessary movement of people. In addition, three other types of waste are being reduced indirectly by the cellular physical arrangement as a result of applying process improvement techniques, using small batches and total quality control. They are inadequate processing, stocks (as discussed previously, due to lack of space for this waste in a cell), and production of defective products. The only loss that does not seem to be directly influenced by the cell is overproduction. However, overproduction is avoided for two reasons: cells are implemented to support lean thinking, which tends to minimize the surplus production, and the cells can respond quickly to market changes, which reduces the need to maintain stocks (Hyer \& Wemmerlöv, 2002). Yet, other advantages were perceived in the application of cellular layout, such as reduction of production space required by up to $50 \%$, improvements in productivity, increased product quality, and stimulation of continuous improvement (Hunter \& Black, 2007).

In pursuit of these benefits, lean concepts and cellular layout started to be implemented in the remanufacturing environment, as reported in the work of authors: Amezquita and Bras (1996), Aksoy and 
Gupta (2005), Sundin (2006), Hunter and Black (2007), Mähl and Östlin (2007), Östlin and Ekholm (2007), and Kucner (2008).

\section{Remanufacturing}

The products may be returned from the field by two reverse distribution channels: post-consumer and post-sales. The reverse channel of post-consumer is characterized by products originating from disposal after use. The reverse channel post-sales is characterized by the return of products with little or no use that presented problems of responsibility of the manufacturer or distributor and, also, by consumer dissatisfaction (Leite, 2003). On the occasion of return, products can proceed to some destinations, referred here as scenarios for the returned product. Parkinson and Thompson (2003) developed taxonomy to classify these possible end-of-life scenarios, as Figure 2 shows.

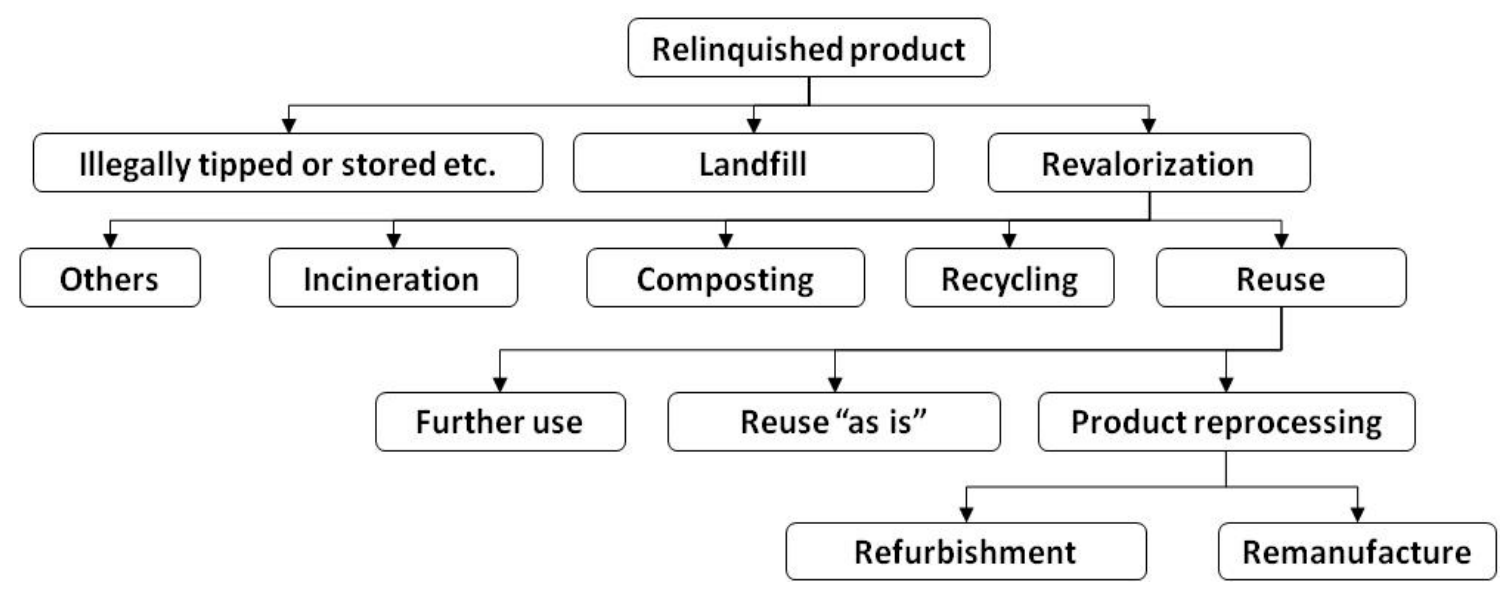

Figure 2. End-of-life scenarios. Source: Adapted from Parkinson and Thompson (2003).

Among the scenarios in Figure 2, remanufacturing is considered the most economically sustainable form of reuse of manufactured goods (Amezquita \& Bras, 1996), presenting several benefits and opportunities (Kucner, 2008).

\section{Definition of Remanufacturing}

When it comes to remanufacturing, this term is usually confused with other processes that are applied to products at the end of the life cycle (Puglieri, 2009). There is no consensus in academia and in the industrial environment on the most correct terminology for dealing with product recovery (Lindahl, Sundin, Östlin, \& Björkman, 2006). The literature is diverse, with views, definitions, and descriptions widely different (Parkinson \& Thompson, 2003).

Therefore, remanufacturing can be defined as an industrial process where used products, called cores, are returned to their original specifications and conditions (Amezquita \& Bras, 1996; Guide Jr., Souza, \& Van Der Laan, 2005; Ijomah, Mcmahon, Hammond, \& Newman, 2007) through the repair or replacement of parts or components (Ijomah et al., 2007). That is, the remanufacturing transforms used or defective products into new products with a new life cycle (Östlin, Sundin, \& Björkman, 2009). It can be stated, therefore, that the purpose of remanufacturing is to reprocess used products so that their quality is as good, or greater, than the new, in terms of appearance, reliability, and performance (Parkinson \& Thompson, 2003).

For this article, the following definition is accepted: "Remanufacturing is to recover worn-out/broken/used 
product to its original specifications through an industrial process that may or may not modernize it with new specifications, promoting the reuse of materials and improving their quality and functionality” (Bouzon et al., 2010).

\section{Remanufacturing Stages}

The remanufacturing process, in general, is divided into the following operations: disassembly, cleaning, inspection and sorting, repair or replacement of parts, reassembly, and testing (Parkinson \& Thompson, 2003; Sundin, 2004), as in Figure 3. These operations can be placed in a different sequence or excluded, depending on the type of product, volume, quality of the returned item, and the purpose of remanufacturing. Different industries choose to perform these operations in different sequences (Sundin, 2004).

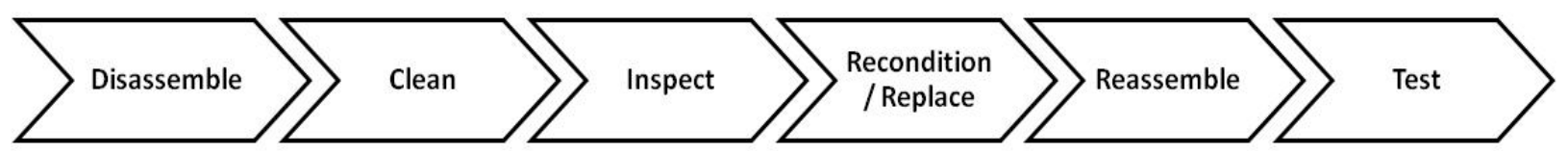

Figure 3. Remanufacturing stages. Source: Adapted from Parkinson and Thompson (2003).

In their paper that evaluated the state of the art technology in remanufacturing, Nasr et al. (1998) and Guide Jr., Jayaraman, and Srivastava (1999) stated that most of the work stations in this environment use equipment which are little automated. The majority (85\%) of remanufacturing companies use conventional manual equipment to process materials. Less than $25 \%$ use CNC or NC machines, and a very small percentage—around 6\%—uses the cellular layout for remanufacturing.

\section{Proposal of Cellular Layout for Remanufacturing}

The efficiency in the context of remanufacturing, in general, is still below the levels of traditional manufacturing. Remanufacturing has remained untouched by technology, productivity, and quality improvements over the last 30 years and is, therefore, called as "immature industry" (Kucner, 2008). Moreover, in his comparative study between manufacturing and remanufacturing, Sundin (2004) concluded that the remanufacturing industries have below-average performance compared to manufacturing regarding material flow issues.

As a solution to this inefficiency, the application of cellular layout based on lean principles can contribute to the growth of this industry and help in the creation of flow. However, these principles should be applied in remanufacturing with restrictions due to the particularities of their environment (Sundin, 2006; Östlin \& Ekholm, 2007; Kucner, 2008).

\section{Premises for the Creation of Cellular Layout in Remanufacture}

For the creation of a cellular physical arrangement in the remanufacture, one must consider the variability of supply of this environment (product reverse logistics), variability of work content due to variation in the quality of goods returned, and the difficulty in balancing the return of products (supply) with the demand (market of reuse). For these questions, it can said that a remanufactured product is like a product covered by the type of production called engineered-to-order (ETO), with different specifications and content of work unique to each production unit. Thus, remanufacture requires flexibility because the variability is inherent in its processes. Therefore, the proper application of the cellular layout in this environment should better manage the tradeoff between flexibility and efficiency to transform the "immature industry" in a lean remanufacture. 


\section{Configuration and Operation of the Cellular Layout in Remanufacture}

The application of work cells and process standardization in the remanufacture helps to build limits on the sources of variation. Because the environment is often unstable, the standardization of processes should not be highly detailed, just enough to provide flexibility and ensure quality. The production team must be highly trained, but not specialized, and with a high degree of knowledge to perform complex repairs. And yet, to maintain an acceptable productivity in a highly variable environment, there should be used buffers (stocks with controlled level) of strategically placed resources such as tools, material, and manpower. The irregularities of the process should be alerted through the visual management, inspiring the continual improvement of processes.

Figure 4 shows the design of the proposed cellular layout for the remanufacturing environment, presented in a simplified way in order to be generic and didactic. The products discarded or relinquished (DP) are first submitted to an initial test run to check the product model, their state, and defects presented. Subsequently, the products are selected as remanufacturable or not and classified according to their scope of work for the remanufacturing at the recovery cells $(1 \ldots \mathrm{n})$. Thus, at this stage, some products may be discarded for disposal or recycling. The products for repair (PR) head for the recovery operations of the cells, where they are disassembled, cleaned, repaired, and finally undergo final test operation. This separation in different recovery cell is justified when there is sufficient volume of return for the different scopes of work of remanufacturing. At the end of each cell, a remanufactured product (RP) is obtained. If the product does not yet offer the desired quality in the final test, the product may undergo further tests and return to the beginning of the cell for repair, or be discarded if the problem is irreparable.

After the repair of the product, the reassembly operation can be performed on the countertop of repair, before or after the final test, depending on the geometry of the product and the needs of test execution (assembled or disassembled). In the support operations, cell supply occurs periodically from the outside, namely, the supplier does not need to enter the cell to provide the necessary materials, which could cause interruptions in the productive flow. This same supplier can collect the parts and materials rejected in the operations of disassembly and repair.

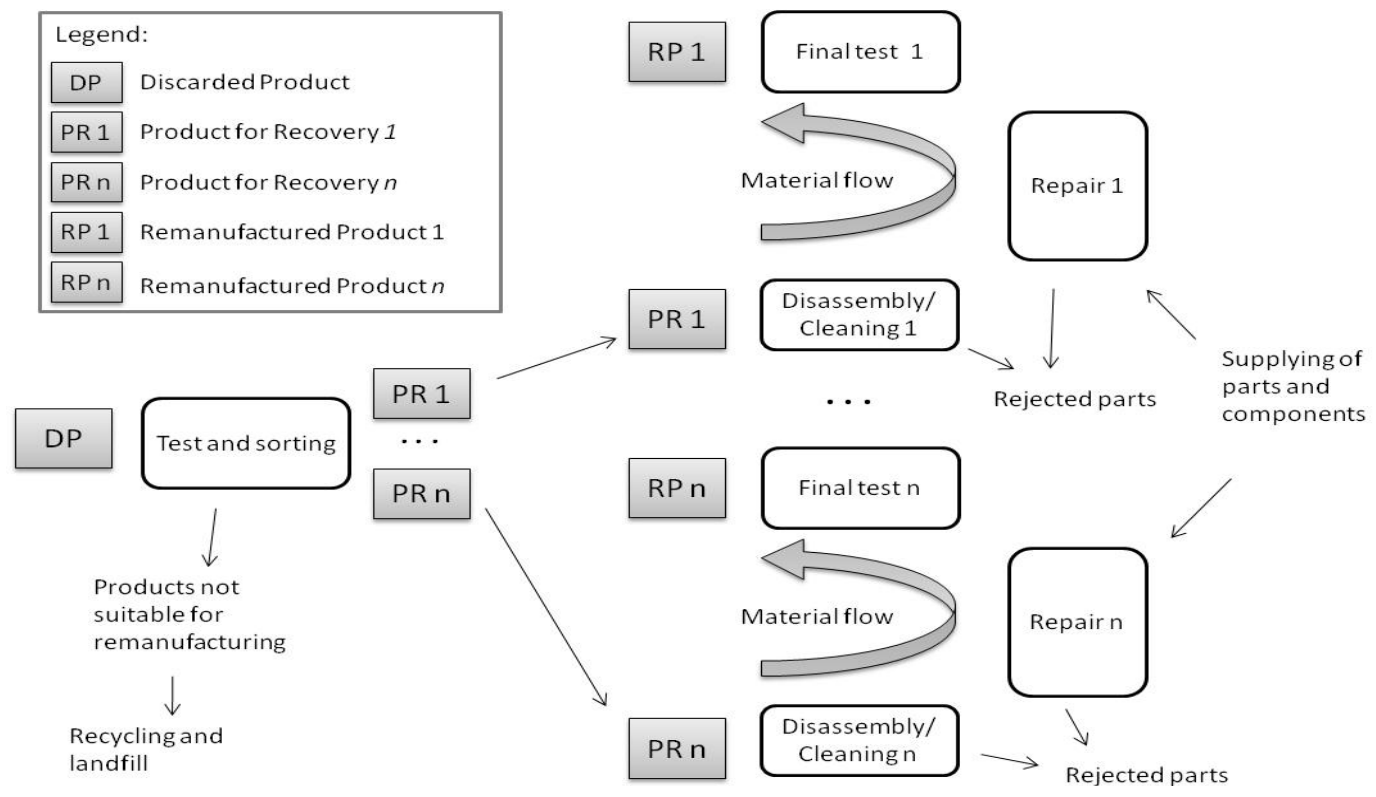

Figure 4. Proposed cellular layout for remanufacturing. 
Thus, in this cellular layout configuration presented, each cell is responsible for a range of products in order to remanufacture, in the same cell, products that require similar operations, minimizing the variation of the total content of work and setup times, facilitating the standardization of the activities and increasing the productivity of the cells and the quality of products remanufactured.

\section{Final Considerations}

The legislative and environmental issues have influenced the search for solutions to the end of life of products. Remanufacturing, as a form of revalorization of goods, is a growing industry, but faces obstacles related to its context. These adversities make its environment a poorly developed one in terms of technology, quality, and productivity, if compared to manufacturing.

This article brought as contribution the proposal of a cellular layout for the environment of recovery of products. The cellular physical arrangement, within the scope of lean thinking, can help the remanufacturing industry to achieve higher levels of productivity, reducing waste (non-value added activities) and increasing the quality of products remanufactured. This layout, if applied considering the restrictions of the recovery environment of products, can provide the flexibility to handle the variations inherent in the context of remanufacturing.

It is also important to mention that the volume and frequency of return of the products are essential to maintain the flow and enable the use of a cellular layout in remanufacturing. Balancing this return flow with the demand is also a challenge for product recovery environments and a crucial element to keep the business profitable and sustainable. For this, much work should be done in reverse logistics, as well as on the demand side, for the reuse market. This remanufactured product market must rely on the quality of recovered products in order to be consolidated. In this context, the cellular layout assists in standardizing processes, providing better quality for consumers of second hand products.

Future research can be developed within the remanufacturing in cell field, focusing on material handling of the recovery cells in order to meet the need for flexibility in this environment. The development of studies in the field of product recovery, besides enabling the maturation of this type of industry, may also reflect on the economic management of reuse, as well as contribute to the social and environmental sustainability of the business.

\section{References}

Aksoy, H. K., \& Gupta, S. M. (2005). Buffer allocation plan for a remanufacturing cell. Computers and Industrial Engineering, 48, 657-677.

Amezquita, T., \& Bras, B. (1996). Lean remanufacture of an automobile clutch. Proceedings from International Working Seminar on Reuse, Eindhoven.

Baudin, M. (2002). Lean assembly. New York, N.Y.: Productivity Press.

Bouzon, M., Cardoso, C. L., Queiroz, A. A., \& Gontijo, L. A. (2010). Practical-theoretical overview of product recovery environment: A case study in a telecom remanufacturing. Proceedings from $X X X$ ENEGEP, São Carlos.

Guide Jr, V. D. R., Jayaraman, V., \& Srivastava, R. (1999). Production planning and control for remanufacturing: A state-of-the-art Survey. Robotics and Computer-Integrated Manufacturing, 15, 221-230.

Guide Jr., V. D. R., Souza, G. C., \& Van Der Laan, E. (2005). Performance of static priority rules for shared facilities in a remanufacturing shop with disassembly and reassembly. European Journal of Operational Research, 164, 341-353.

Hunter, S. L. \& Black, J. T. (2007). Lean remanufacturing: A cellular case study. Journal of Advanced Manufacturing Systems, 6, 129-144.

Hyer, N., \& Wemmerlöv, U. (2002). Reorganizing the factory. New York, N.Y.: Productivity Press. 
Ijomah, W. L., Mcmahon,C. A., Hammond, G. P., \& Newman, S. T. (2007). Development of design for remanufacturing guidelines to support sustainable manufacturing. Robotics and Computer-Integrated Manufacturing, 23, 712-719.

Kucner, R. J. (2008). A socio-technical study of lean manufacturing deployment in the remanufacturing Context (Ph.D. thesis presented at University of Michigan, Detroit).

Leite, P. R. (2003). Logistica Reversa: Meio ambiente e competitividade. New York: Prentice Hall.

Liker, J. K. (2004). The Toyota way: Fourteen management principles from the world's greatest manufacturer. New York, N.Y: McGraw-Hill.

Lindahl, M., Sundin, E., Östlin, J., \& Björkman, M. (2006). Concepts and definitions for product recovery: Analysis and clarification of the terminology used in academia and industry. Proceedings from CIRP International Seminar on Life Cycle Engineering, Grenoble.

Mähl, M., \& Östlin, J. (2007). Lean remanufacturing: Material flows at Volvo Parts Flen (Master thesis presented at Uppsala University, Uppsala).

Ohno, T. (1997). Toyota production system: Beyond large-scale production. New York, N.Y.: Productivity Press.

Östlin, J., \& Ekholm, H. (2007). Lean production principles in remanufacturing: A case study at a toner cartridge remanufacturer. Proceedings from IEEE International Symposium on Electronics and The Environment, Orlando.

Östlin, J., Sundin, E., \& Björkman, M. (2009). Product life-cycle implications for remanufacturing strategies. Journal of Cleaner Production, 17, 999-1009.

Parkinson, H. J., \& Thompson, G. (2003). Analysis and taxonomy of remanufacturing industry practice. Proceedings of the Institution of Mechanical Engineers, Part E: Journal of Process Mechanical Engineering, 217, 243-256.

Parkinson, H. J., \& Thompson, G. (2004). Systematic approach to the planning and execution of product remanufacture. Proceedings of the Institution of Mechanical Engineers, Part E: Journal of Process Mechanical Engineering, 218, 1-13.

Peinado, J., \& Graeml, A. R. (2007). Administração da Produção. Curitiba: UnicenP.

Puglieri, F. N. (2009). Proposição de um Método para a Remanufatura Baseado em QFD. Proceedings from International Workshop/Advances in Cleaner Production, São Paulo.

Rother, M., \& Harris, R. (2002). Creating continuous flow (translated Portuguese). São Paulo: Lean Institute Brasil.

Slack, N., Chambers, S., \& Johnston, R. (2008). Operations management (translated Portuguese). São Paulo: Atlas S.A..

Sundin, E. (2004). Product and process design for successful remanufacturing (Master Thesis presented at Linköpings Universitet, Linköpings).

Sundin, E. (2006). How can remanufacturing processes become leaner? Proceedings from CIRP International Conference on Life Cicle Engineering, Leuven).

Womack, J. P., \& Jones, D. T. (2004). Lean thinking (translated Portuguese). Elsevier: Rio de Janeiro.

Womack, J. P., Jones, D. T., \& Roos, D. (2004). The machine that changed the world (translated Portuguese). Rio de Janeiro: Elsevier. 